\title{
Article
}

\section{The multi-layered transnationalism of Fran Palermo}

Mazierska, Ewa Hanna and Kránicz, Bence

Available at http://clok.uclan.ac.uk/21230/

Mazierska, Ewa Hanna ORCID: 0000-0002-4385-8264 and Kránicz, Bence (2017) The multi-layered transnationalism of Fran Palermo. Popular Music History, 10 (3). pp. 241-261. ISSN 1740-7133

It is advisable to refer to the publisher's version if you intend to cite from the work. http://dx.doi.org/10.1558/pomh.35325

For more information about UCLan's research in this area go to http://www.uclan.ac.uk/researchgroups/ and search for < name of research Group>.

For information about Research generally at UCLan please go to http://www.uclan.ac.uk/research/

All outputs in CLoK are protected by Intellectual Property Rights law, including Copyright law. Copyright, IPR and Moral Rights for the works on this site are retained by the individual authors and/or other copyright owners. Terms and conditions for use of this material are defined in the policies page.

\section{CLoK}

Central Lancashire online Knowledge www.clok.uclan.ac.uk

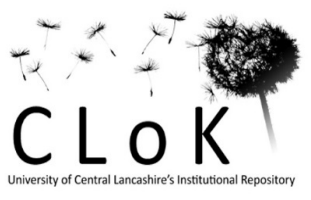




\title{
The Multi-layered Transnationalism of Fran Palermo
}

\section{Ewa Mazierska and Bence Kránicz}

\begin{abstract}
Fran Palermo is an indie band based in Budapest which started performing in 2011, initially as a cover band, and so far produced over 30 original songs and 2 LPs, 'Fran Palermo' and 'Razzle Dazzle', in 2015 and 2016 respectively, to a significant critical acclaim. Its current line-up includes eight musicians, with Henri Gonzalez, a musician of Cuban and Spanish descent, being its leader.
\end{abstract}

This article considers the transnational character of Fran Palermo's work in the context of the history of pop-rock in Hungary and Eastern Europe at large, arguing that it does not fit the prevailing narrative of Eastern European music as imitator of a Western idiom. The lyrics often engage with exotic landscapes, and are populated by touristy clichés, yet the way they are juxtaposed, suggest that the band does not try to recreate realistically an experience of travelling to the South, but rather play with its representations. The large number of instruments, including a trumpet, two saxophones and a conga, allows for creating a rich, eclectic sound. The music betrays a multitude of influences, from Anglo-American rock to South-American and African music.

The study draws on the idea of 'world music', understood as a music produced in the periphery and offered to western consumption. Our argument is that Fran Palermo's music complicates this idea, as it originates from the place which is neither West nor a typical East, and it is produced by neither westerners nor 'proper' easterners, neither outsiders nor insiders. We also use the concept of heterotopia to explain textual characteristics of Fran Palermo's music.

Our primary source is an interview which we have conducted with two members of the band, Gonzalez and Dimitris Topuzidis in July 2016, two concerts of Fran Palermo we attended in summer of the same year and their songs and performances available on YouTube.

\section{Key words}

Fran Palermo, Hungarian music, transnationalism, world music, Spain, Orient.

Ewa Mazierska is Professor of Film Studies, at the University of Central Lancashire. She published over twenty monographs and edited collections on film and popular music. They include Popular Music in Eastern Europe: Breaking the Cold War Paradigm (Palgrave, 2016), Relocating Popular Music (Palgrave, 2015), edited with Georgina Gregory, From Self- Fulfillment to Survival of the Fittest: Work in European Cinema from the 1960s to the Present (Berghahn, 2015), Falco and Beyond: Neo Nothing Post of All (Equinox, 2014) and European Cinema and Intertextuality: History, Memory, Politics (Palgrave Macmillan, 2011).

\section{Address}

17 Grove Crescent, Adlington, Lanc., PR6 9RJ, UK

E-mailEHMazierska@uclan.ac.uk 
Bence Kránicz is a journalist and a PhD student at the Film, Media and Contemporary Culture Programme of Eötvös Loránd University in Budapest. His articles on film, literature, comic books and music have been published in various Hungarian magazines since 2009.

\section{Address \\ 1123 Budapest, Csörsz u. 1., Hungary \\ E-mail kranicz.bence@gmail.com}

Fran Palermo is an indie band based in Budapest which started performing in 2011, initially as a cover band and so far produced over 30 original songs and 2 LPs, 'Fran Palermo' and 'Razzle Dazzle', in 2015 and 2016 respectively, to significant critical and popular acclaim, as reflected by the fact that in 2016 it received an award for the best upcoming band at the Petoffi Live Awards, a prize given out by the state-funded popular music radio channel.

Its current line-up includes eight musicians, with Henri Gonzalez being its leader and the principal author of the lyrics and music. The band is young not so much in terms of their experience, as their age. The majority of its members are in their early twenties with Gonzalez being born in 1993. Its size, rather unusual for contemporary pop-rock bands, is explained by its origin and a way to find its audience. It was a band made up of schoolmates who liked to hang out together. Creating music was a means to prolong their pleasure. Having eight members meant that more friends could be brought to their early gigs than if the band had only three or four, as each member was expected to bring ten friends. This strategy paid off, as in a short period it gained a sizeable fan base and currently their largest concerts have an audience counted in thousands. This is also reflected in the size of their virtual audience. Their most popular songs, Morning Waltz and Am I Right Boy, have each over 100,000 YouTube hits.

In this article we consider the transnational character of Fran Palermo's work, arguing that its transnationalism is multi-layered and does not easily fit into the dominant narrative of the development of Eastern European pop-rock nor the concept of 'world music'. To demonstrate this, we will draw on the work of transnationalism in popular music, as well as a history of pop-rock in Hungary and Eastern Europe at large. Our primary source is an interview which we have conducted with two members of the band, Gonzalez and Dimitris Topuzidis in July 2016, two concerts of Fran Palermo we attended in summer of the same year and their songs and performances available on YouTube.

\section{$\underline{\text { Eastern European pop-rock as transnational music }}$}

It is a truism to say that pop-rock is transnational. However, there are different ways to theorise it. On the one hand, we find the concept of 'cultural imperialism', according to which Anglo-American pop-rock 'displace and appropriate authentic representations of local and indigenous music into packed commercial music commodified for ethnically indeterminate, but predominantly Anglocentric and Eurocentric audience' (Mitchell 1996: 1). On the other hand, we encounter a more democratic idea of 'aesthetic cosmopolitanism', espoused by Motti Regev, who sees pop-rock as pertaining to late modernity and consisting of an intensified aesthetic proximity, overlap, and connectivity between nations and ethnicities or, at the very least, between prominent large sectors within them. Regev argues 
that under late modernity the expressive forms of cultural practices used by nations and by groupings within them, share much common ground, becoming a unit within one complex entity (Regev 2013: 3). Although quite different from each other, the two concepts are based on the conviction that pop-rock develops towards a greater homogeneity.

Applying the model of 'cultural imperialism' to pop-rock in Eastern Europe of the Cold War period is problematic, because governments in state socialist countries limited their cultural exchange with the West, by censoring the import of Anglo-American music, as well as restricting opportunities of local artists to travel to the West and absorb their influences. Seeing Eastern European pop-rock in terms of cultural imperialism is also tricky because artists from there usually willingly borrowed from the West. Hence, the concept of selfcolonisation seems to be more pertinent to this region and this framework has a particular appeal to authors discussing pop-rock in Eastern Europe in Western publications. Some of the more dramatic passages written by authors such as Timothy Ryback and Sabrina Ramet, state that drawing on English and American rock was a form of rebellion against the dominant state socialist system by infecting oneself with western values to which state socialism was hostile (Ryback 1990: 3-6; Ramet 113994). But there are also problems with applying this idea. One consists of sentencing Eastern European pop-rock to the position of a poor relative of its Anglo-Saxon cousin. Furthermore, seeing Eastern European pop-rock merely as a product of imitation of western models disregards rare, yet existent cases when Anglo-Saxon artists borrowed from the East, as with David Bowie's Warsaw or the more obvious case of Kanye West sampling Omega's Pearls in Her Hair. Neither does it consider situations when the source of inspiration for Eastern European artists was other 'peripheral' cultures, for example Greek or South American music.

Given the abovementioned difficulties, Regev's model of 'aesthetic cosmopolitanism' comes across as more suitable to capture the position of Eastern European pop-rock during the Cold War. It suits even better postcommunist times and especially the period after the digital shift when online platforms such as YouTube give the impression that music from all over the world exist in close proximity to each other and there are infinite ways of infecting oneself with music from elsewhere, as well as affecting others with their own music. Under such circumstances using English, which in the case of Eastern European artists was previously seen as a sign of artistic immaturity or even inability to create their own idiom of expression, can be regarded as a purely pragmatic choice, increasing the chance of reaching a potentially global audience. For this new generation of artists, to whom Fran Palermo belongs, English is a new 'lingua franca', or to use Juliane House's terminology, a 'language of communication', rather than a 'language of identification' (House 2003). ${ }^{1}$ This means that writing lyrics in English does not need to signify an allegiance to the music created by the Beatles or the Rolling Stones and English culture at large, but rather is a sign of willingness to belong to a global music scene.

\section{Hungarian pop-rock after the digital shift}

While during the Cold War Hungarian artists aiming for international fame faced geographical, cultural and political barriers, after the change of the political system from state socialism to neoliberalism and, more importantly, after the digital shift, these barriers gradually eroded. As Anna Szemere, the leading specialist on Hungarian popular music noticed in her book from 2001: 'For many actors in the field, the transition has opened up new terrains of creativity and offered a sense of autonomy, choices of lifestyle and career that

\footnotetext{
${ }^{1}$ Juliane House observes that the number of non-English speakers is about 4 times as high as of native speakers. English is thus no longer owned by its native speakers (House 2003: 557).
} 
earlier were unthinkable. Now they can tour abroad, form bands with foreign musicians, run alternative boutiques and clubs, direct pop music programs on cable television' (Szemere 2001: 17-8). Hence, it seems that after 1989, and especially in the 2000s, it is enough to come up with songs relevant to the international market, namely songs applying conventions of western pop-rock genres and sung in English, to reach international recognition.

Yet, paradoxically, international fame was in a way easier to achieve under the state socialist regime, because some Hungarian, German or Polish bands travelled easily in the Eastern Bloc, and occasionally they were presented in Western Europe, the United States or even Asia as curious products of the communist part of Europe. Among Hungarian bands, arguably Omega was the most successful abroad. It released several LPs and EPs in English and even in German; their first English-language LP, 'Omega, Red Star from Hungary', was released in 1968, the same year as Omega's first Hungarian-language album (Csatári and Jávorszky 2016). LGT and Neoton Família also frequently travelled to countries of the Eastern Bloc or even further. The destination of LGT's first international tour was Japan, and they also released seven LPs and several EPs in English, despite the fact that their tours were under close surveillance by communist bureaucrats (Fesztival.mandiner.hu 2015). All these bands achieved international successes despite the fact that their songs were mostly written in Hungarian and their members had problems to communicate in English.

The change of the political system meant that Hungarian performers could travel to Western Europe more easily, so it comes as no surprise that in the 1990s many upcoming bands recorded their debut songs and records in English. Pop-rock bands easily adapted to this situation also because many of these artists believed that writing pop lyrics is harder in Hungarian than in English. Echoing this opinion, Henri Gonzalez also said that English is the 'real language' of pop music; hence his decision to write lyrics chiefly in English. However, writing in English did not always mean engaging with this language at a deeper level. For example, András Lovasi, the lead vocalist and bass player of the most popular alternative rock band of the 1990s and 2000s in Hungary, Kispál és a Borz, once said in a TV show, that their method of writing songs consisted of improvising 'English-sounding gibberish' to halfready tunes, which later they converted into Hungarian lyrics. ${ }^{2}$ Two other popular bands of the 1990s and 2000s, Heaven Street Seven and Quimby (whose very names were conceived with an eye on the international market) recorded their first albums in English. Yet, by the mid-to-late 1990s they realized they should focus on the local market. 'Majomtangó', Quimby's first album recorded on a CD, contained only three songs in English, and the rest of the album was in Hungarian. ${ }^{3}$ Heaven Street Seven,'s third album, 'Budapest Dolls', was the first one with Hungarian-language songs. ${ }^{4}$ Its title localized the band in Hungary, but the fact that it has an English title indicates that the band strove for both Hungarian and international success. Both Quimby and Heaven Street Seven achieved local fame and success with their consecutive Hungarian albums and Hungarian-language hit songs, which

\footnotetext{
${ }^{2}$ The traces of this method are also present in the chorus of a song from Lovasi's second band, Kiscsillag: the chorus (and the title of the song) is Van-e szándék? ("Are you willing?"), which sounds like and is pronounced as "one sunny day", the original improvised line for the chorus.

${ }^{3}$ The same rule, namely moving to English from a native language and back to the native language pertains also to many Russian rock bands after the fall of state socialism (Gorbachev 2015).

${ }^{4}$ A similar turn to English can be observed also in Hungarian postcommunist cinema. As Andrea Virginas observes, characters in many Hungarian films of this period frequently use English. For example, in Just Sex and Nothing Else, modelled on the structure of webpage searches, some of the words are already in English, recalling internet practice. The most successful 2013 film Coming Out and the 2014-2015 hits Swing (2014) and Argo 2 already encode 'Englishness' in their titles (Virginas 2017, forthcoming).
} 
made them two of the most popular bands of the 2000s in Hungary, following Kispál és a Borz, who also opted for Hungarian-language songs.

At the turn of the millennium it seemed that international fame was something Hungarian bands could aspire to, but not reach. This situation first changed in the field of electronic music, with Yonderboi releasing his first EP, Cinnamon Kisses in Hungary, with a cover of Riders on the Storm by the Doors, which found its way to some international 'bestof' selections of electronic music. After that Yonderboi got an opportunity from a German record label to produce his first LP in Germany, and this led to the release of 'Shallow and Profound' in 2000. Subsequently, Yonderboi simultaneously built his local and international career - the song 'Were You Thinking of Me' from his second album was even selected as a track for a FIFA football video game in the 2000s.

By 2010, online music platforms such as YouTube, MySpace and Soundcloud have been popular in Hungary. This meant that the gap in music knowledge between Hungarian and western bands was closing rapidly. The same records, styles and tendencies could be accessed and appropriated all over the world. Also, by uploading their songs onto the internet, Hungarian bands could easily send samples of their work to international record companies, and after Hungary joined the European Union in 2004, it was also easier legally to initiate international releases and labels, such as the electronic label Farbwechsel, founded in Budapest, but cooperating frequently with British or German labels (Klág 2016). This period overlapped with the international trend of lo-fi rock. The lo-fi bands intended to sound slightly amateurish and offbeat. This worked in favour of Hungarian bands, which typically lacked the same technical resources as their western counterparts, but they could easily join the lo-fi wave. Upcoming Hungarian bands found their way to the 'best-of' lists of British and American online music magazines, and this type of 'internet fame' slowly introduced some Hungarian bands to the international market (Recorder.blog.hu 2011). This is the context in which Fran Palermo started to operate in 2011, although not as part of the lo-fi movement, which slowly faded by around 2014, but as a 'jungle' or 'tropical' rock (as the band presents itself on their Facebook page), which brings association with world music.

\section{$\underline{\text { The discourse of world music }}$}

When discussing the transnational character of Fran Palermo, it is also worth evoking the concept of 'world music'. This term, in common usage, does not designate the totality of popular music produced in the world ${ }^{5}$, similarly as the term 'world cinema' does not refer to the global film production. Instead, both terms refer to artistic production created outside the western world, at what can be described as the 'global periphery'. As Jocelyne Guilbault claims, "world music are taken to be those musics which come from outside the "normal" Anglo-American (including Canadian and Australian) sources, and mainly from tropical countries' and 'is the product of aggrieved populations, either from third world countries (Africa and the African diaspora) or from disadvantaged population groups in a general sense' (Guilbault 2001: 176).

Furthermore, world music, like world cinema, needs to be accessible to the western audience, which requires it to be subjected to the same processes of standardisation as the music produced in the centre. Hence the often condescending attitude to this phenomenon by a part of the audiences, who see it as a product geared towards tourists, as opposed to the

\footnotetext{
${ }^{5}$ However, according to Timothy Taylor, 'as early as the late 1970s and early 1980s some ethnomusicologists were using the term world music to describe all the musics of the world's peoples' (Taylor 1997: 2).
} 
'authentic stuff', which is less easily available, even hidden from western eyes (Connell and Gibson 2003: 144-59). However, even those authors who do not accuse world music of inauthenticity or kitsch, emphasise the fact that this music is, in a sense, a western product. Philip Bohlman presents it as a product of the encounter between the West and 'the rest' (of the world). 'Asserting that there is music everywhere in the world is... a Western concept, if it is also, however, a concept that results from Western encounters with the world' (Bohlman 2002: xvi; see also Erlmann 1996). One can see a link between 'world music' and Orientalism, as conceived in the classical book by Edward Said (2003), as both Said and Bohlman argue that the power of the representation of the periphery lies at the centre, not the periphery. The East is thus a western creation.

When discussing 'world music', we have to take into account its different stages and dimensions, such as production, marketing and consumption. A particular music might be created in Africa, but never offered to western consumers (Fairley 2001). The term 'world music' is invoked not only when musicians from tropical countries attempt to gain popularity outside their countries, but also when westerners draw on non-western music, either for the sake of their own popularity or for the more noble purpose of preservation of this music and the empowerment of peoples from around the world. In this context names such as Paul Simon and Peter Gabriel are frequently evoked, because both performed and recorded with artists from what was known as the Third World (Taylor 1997: 21-2 and 39; Fairley 2001: 273).

The term 'world music' has been rarely used in the context of Eastern Europe. This is because this region, being part of Europe, was not regarded as exotic or oppressed enough to be consumed as 'world music'. Equally, it did not have enough (post)colonial power to be seen as a convincing advocate of disadvantaged peoples.

However, during the Cold War, especially in the 1950s, we could find numerous references to exotic locations, especially Cuba, in the songs produced in Eastern European countries. Their existence can be explained by two factors. One was the political situation when it was safer to mention in songs countries and cultures not regarded as western, but friendly or neutral towards state socialism. The second factor was Eastern Europeans yearning for a 'proper' tropical holiday, which was beyond the reach of the vast majority of them. Two of the biggest hits of the 1980s in Hungary, Neoton Família's 'Isztambul' and KFT's 'Afrika', use exotic places in their titles and lyrics as a metaphor for leaving behind the dull everyday life of Eastern Europe.

These attempts at self-orientalisation (understood as infecting oneself with nonEuropean and non-western influences) were treated with derision by local critics, as they allegedly betrayed at best a superficial knowledge of musics and customs of the places the artists referred to and they felt more inauthentic than the attempts at imitation of western music. ${ }^{6}$ reIn the postcommunist period the attempts to create something akin to 'world music', namely music drawing on oriental influences, have still been rare. Even against the background of Eastern European 'world music' Fran Palermo comes across as unique, due to the breath of its influences and the band's ability to rework them to create an original work. Moreover, while the ethnically Hungarian, Czech or Polish musicians singing about oriental

\footnotetext{
${ }^{6}$ One notable exception is a Polish punk band Maanam, who in their songs from the 1980s frequently mentioned exotic locations, as in Boskie Buenos (Divine Buenos). However, on this occasion the musicians did not pretend to know the distant places, but usually used them to project ironically an image of spoilt stars who travel all over the world (as in this song) or used the elements of the (stereotyped) Orient to create imaginary, surreal landscapes.
} 
landscapes by default come across as fake, unless they imbue their work with irony, an artist whose roots are in the 'world', as is the case of Gonzalez, does not evoke such a reaction.

In the remaining part of this essay we discuss various aspects of Fran Palermo's work, such as their lyrics, music and record covers, to show how they engage with and rework elements of foreign cultures to create their own brand of music.

\section{The layers of transnationalism of Fran Palermo: people, lyrics, music}

Fran Palermo is transnational at many levels, beginning with its line-up. Its leader, Henri Gonzalez has a Cuban father, who is also a musician, and a Spanish Hungarian mother, a former ballerina. His parents, who before settling in Cuba resided in Mexico and Russia, relocated to Hungary in the early 1990s on the advice of Henri's Hungarian grandmother, to take advantage of the better living conditions there. Among the members of Fran Palermo is also Henri's brother Daniel and Dimitris Topuzidis, who is half-Greek, while the manager of the band, Álmos Galeotti, is half-Italian.

The story of Fran Palermo testifies to the fact that it is much easier for Hungarians to travel after state socialism ended and especially after Hungary joined the European Union in 2004 than ever before. However, this ease has worked against the band's cohesiveness, as demonstrated by the fact that from its inception there has been about 20 different musicians in it and those who left did so to study and work abroad, in countries such as Austria and the UK. To some extent this also applies to Gonzalez, who in 2013 suspended the operations of Fran Palermo and moved to London, to pursue a musical career there and stayed in this city for one and a half years. During this period he supported himself by manual work and tried unsuccessfully to make a record in an English studio. The labels whom he approached were not interested in investing in a newcomer from the periphery with less than perfect English pronunciation and he could not afford to finance the recordings from his own pocket. The only tangible result of this period, apart from some pictures showing him basking in various London locations, is a professional video for one of Fran Palermo's most popular songs, 'Am I Right Boy', in which Gonzalez performs as 'Ruby' (a stage name he came up with himself), shot by Anders Brogaard, working for Burberry, one of the most successful non-music brands which took advantage of online technology to create its own 'in-house' musical platforms, in this case Burberry Acoustic (Barton 2013). Subsequently the video was sent to some record labels, but nothing followed from that and a disillusioned artist returned to Budapest to resume working with Fran Palermo. Gonzalez's London adventure points to the fact that while the political and technological developments of the 1990s and 2000s lowered the bar for entry of Eastern European musicians to the global market, they raised the bar for their success. Ironically, during his absence from Hungary, Fran Palermo's songs got some traction with the local audience and when the band resumed its operations in 2014 it was more popular than ever before. Although unique, the story of Fran Palermo also speaks volumes about the mobility of contemporary young Eastern Europeans, for whom the UK is a favourite destination, as well as the mythologisation of London as a special place for musicians. When talking to the members of the band, we heard them say that 'making it in England' is their ultimate artistic goal.

While on the real and imaginary map of Fran Palermo's travels London has a privileged place, other aspects of its work point to different locations. The name of the band, although according to the band's members does not have any special meaning, being 'just a name', has its origin in the Italian film Malena (2000) by Giuseppe Tornatore, where there is 
a sign 'Fraz Palermo' (direction Palermo). Inevitably, it gestures towards Mediterranean culture and might be read as a sign of Fran Palermo's yearning for the South - a South it never saw, given that the musicians never (physically) reached Palermo. In this context it is worth mentioning that the early influence on Fran Palermo was Beirut, an American band which chose such a name to signify its interest in multiculturalism and a desire to find oneself elsewhere, but without necessarily going there physically.

A similar attitude can be found in their lyrics. They engage with exotic landscapes, at least exotic from the perspective of Hungary, by repeatedly using words such as 'sun', 'blue sky', 'ocean', 'waves', 'island', 'volcanoes' and 'lobster'. It is worth mentioning that Hungary is a small landlocked country, whose largest lake, the Balaton, during the state socialist period played the role of a surrogate Mediterranean Sea for Hungarians, and for many Eastern Europeans. A typical Hungarian might know more about the oriental holiday without leaving his or her country than a Pole or a Czech, but also feels acutely that his or her experience is a surrogate of the 'real thing'. Rather than realistically recreating a perfect day at the beach, somewhere in the Caribbean (which might exist only in holiday brochures), Fran Palermo plays with its representations, adding to them a surrealist twist, as if aware that true Orient cannot be reached, it can only be conjured by inflecting it with a foreign knowledge and sensibility. This can also be deduced from their frequent use of the word 'window', as in the title of their early song 'For the Windows in Paradise', which suggest that the contact with paradise is always mediated.

From the perspective of their engagement with the 'South', Fran Palermo's lyrics can be divided into two categories. The first contains songs dealing with the 'near South': Spain and to some extent Italy. Spanish names are used in titles of several tracks, such as 'Waves of Spain' and 'Coll del Portell' (from the street in Barcelona). These songs describe romantic experiences, such as waiting for a beloved woman in the former song or breaking a relationship in the latter. However, they do not engage with Spain as a distinct geographical or cultural space. The reference to Spain only adds to the mood of yearning or coming to terms with an unrequited love, as in 'Waves of Spain':

Waves sweep the sand

On the shore where we used to stand

I gaze in the past

To see the storm's rush

Thunder above over me

Here comes the flood

Can't see the sun

Over the waves of Spain

Bound me a space between your arms

Let me embrace

Help me escape from the giant waves

Where are you now my only muse?

Where did you hide?

Answer my call if you can still hear me 
For listeners unaware of Gonzalez' ethnic background, such lyrics might signify the unfulfilled Hungarian desire for more dramatic waves than those offered by Balaton ${ }^{7}$ or a condition of a 'modern man' as a 'tourist', who according to Dean MacCannell,'has been condemned to look elsewhere, everywhere, for his authenticity, to see if he can catch a glimpse of it reflected in the simplicity, poverty, chastity or purity of others' (MacCannell 1999: 41). For those aware that he is partly Spanish they gesture towards his lost, yet more real home. At the same time the fact that the topic of these songs is an impossible love, might be read as pointing to the fact that he cannot fully embrace Spain as his homeland.

Songs in the second category gesture towards the further South, as suggested by titles such as 'Monsoon' and 'Tiger Tiger'. However, in 'Monsoon' we find no reference to places affected by monsoons. The only distinct location referenced in this song are 'Chelsea streets', with the 'rolling garbage cans'. Combining Chelsea, presented in such an unflattering way, with 'monsoon' might be seen as a reflection of Gonzalez's disillusionment with London or even the whole mythology of Anglo-Saxon stardom, given that 'Chelsea' is also the name of a hotel in New York, famous for its rock star residents. 'Tiger Tiger' does not refer explicitly to any geographic location where one can find tigers. The eponymous tiger is an imaginary beast who is meant to guide the protagonist through the night. The main point of reference in this song seems to be a poem 'The Tyger' by William Blake, where the eponymous animal is also a nocturnal beast, 'burning bright, in the forests of the night.'

Other song titles also establish the importance of distant, magical worlds, e.g. 'Marc O'Polo' or 'Jankanoo', which is in reality a festival in the Bahamas, or 'Blue Lobster', a song about one of the rarest animal species in the world, probably influenced by Gabriel García Márquez's short film with the same title.

Gonzalez also creates landscapes made of elements belonging to incongruous realities, as in 'Requiem $\mathrm{Nr} 21$ ', where we find 'a white horse', a 'surf board', 'ocean', 'town' and 'jungle' in close proximity to each other. The word 'jungle' in a chorus is next to 'jingle', as if it was a sound without a referent:

Get on the white horse Daisy

I'm gonna ride deep down tonight

I crossed the line, I won't stop

I lose my mind, onto the ride

I ride into the ocean,

The sun just sounds rich in my head.

I found the right way baby...

Pick up your surf board Daisy

I'm gonna drive out of this town...

I drive into the ocean, the sun will shine

We're heading west.

Driving to the jingle jangle, we're gonna leave here, the jungle.

Uncle Bobby's started surrounding the danger zone.

Lyrics of this song, as in 'Waves of Spain', point to a desire to overcome geographical and ontological barriers and arrive in a space where everything can happen, as

\footnotetext{
${ }^{7}$ Sun and sea are also frequent motifs in Abba's songs, which is explained by the Northern dream about Mediterranean holiday (Broman 2005).
} 
in a dream. At the same time, the song makes reference to 'Mr. Tambourine Man' by Bob Dylan, by including the words 'uncle Bobby' and 'jingle jungle', the song which evokes an imaginary, rather than a real journey.

A wish to transcend ontological boundaries is also transmitted by some songs' titles, such as 'Not Penny's Boat', which is a nod to a popular American television series Lost. The characters in this production ended up on a magical tropical island, which was populated by 'smoke monsters' and which disobeyed the laws of physics, allowing its inhabitants to move in time, to the 1970 s and its mythical past.

The collapse of different places and ontological regimes brings to mind the concept of heterotopia. Michel Foucault, who introduced this concept in 1984, defines heterotopias as 'counter-sites, a kind of effectively enacted utopia in which the real sites... are simultaneously represented, contested, and inverted. Places of this kind are outside of all places, even though it may be possible to indicate their location in reality' (Foucault 1998: 231). ${ }^{8}$ The heterotopian effect has much to do with the intertextual character of Fran Palermo's songs. Gonzalez draws on the work of authors who came from South America, such as the previously mentioned Gabriel García Márquez and Julio Cortázar (to whom we will return in due course) or who were fascnated by exotic places, such as Allen Ginsberg whom Gonzalez quotes in 'Casino'.

What is perhaps more important than the real or imaginary locations created in the band's songs is the fact that their protagonist cannot stand still. He is a 'strong swimmer' who 'crosses the channel' or 'crosses the line', while others 'stay in the lighthouse' and are teased by him for being 'lazy boys' or instructed 'never go back'. The focus on movement is underscored by titles such as 'Marc O'Polo', evoking the famous traveller to exotic countries, although written incorrectly, suggesting that Fran Palermo has no ambition to recreate literally Marco Polo's exploits - he is just the symbol of a desire to explore the world. Besides lobsters, horses are the animals most frequently mentioned in Fran Palermo's songs and one of its songs is titled 'Mustangs'. To capture this condition we will use the term 'sojourner music', transplanting this concept from film studies, where 'sojourner cinema' was introduced by Jane Mills in an article published in Framework in 2014. Mills maintains that unlike diasporic or exilic filmmakers, whose productions are inflected with a sense of homelessness or homesickness and who are in-between multiple homes, sojourner filmmakers like to travel, actively seek contact with foreign cultures and are at home in inbetween spaces (Mills 2014). John Di Stefano calls this condition a 'between-home-ness', and states that this is a new paradigm of home for the cosmopolitan where home is 'the routine and habitual practice of mobility itself' (Di Stefano 2002: 41). Gonzalez indirectly confirms reading of his work as that of a sojourner artist by saying in the interviews that he gives little thought to such issues as his ethnic or cultural identity and his dream is to travel and perform everywhere, and especially in far-away locations such as Japan and Israel, rather than merely those to which he belongs due to his ethnic heritage. That said, there is also something diasporic and exilic to the songs of Fran Palermo, most importantly the sense of

\footnotetext{
${ }^{8}$ Mazierska used the concept of heterotopia in her discussion of the songs by Austrian singer Falco (Mazierska 2015), with whom Fran Palermo has much in common.

${ }^{9}$ Sometimes, however, the impression that the world conjured up in Fran Palermo's songs is made of elements which do not suit each other results simply from him writing the lyrics at the last moment, and putting in the text whatever comes to the mind of their author, as was the case of Engrossing (Balkányi 2015).
} 
yearning. Their protagonist does not want to be fixed in one place but his continuous relocations are imbued with melancholy, typically resulting from a break-up of love or friendship.

The vast majority of songs in the repertoire of Fran Palermo are in English, but a minority are in Spanish and the band also did covers of some Hungarian songs. In addition to this, a few years ago they also experimented with performing songs in Turkish, Serbian, Italian and French, and one of their first performances, archived on YouTube, shows them singing the Jewish song 'Hava Nagila'. However, as of July 2016 these songs are not on their usual concert setlists (Zene.ro 2012). Gonzalez himself is a native Spanish and Hungarian speaker, with Spanish being the language in which he communicates with his parents. Bilingualism confers certain linguistic advantages, such as a heightened awareness of the separability of sounds and meanings. In addition, bilinguals have a penchant for ambiguity and are particularly prone to seeing words not as representations of reality but as representations of representations (Beajour 1995). This is true about Gonzalez's take on English. His lyrics, as we argued, tend to be ambiguous, as we are often unsure if he describes real landscapes or only mental images. The phrase 'crossing the line', which one finds in several songs of Fran Palermo, most likely refers to moving from one ontological order to the next, rather than crossing borders between countries and regions. In this context it is worth mentioning that one of Fran Palermo's Spanish songs, 'Van volviendo', uses Julio Cortázar's poem, 'Amor 77':

Y después de hacer todo lo que hacen, se levantan, se bañan, se entalcan, se perfuman, se peinan, se visten, y así progresivamente van volviendo a ser lo que no son.

(And after doing everything they do, they get up, bathe, put perfume, comb, dress, and so gradually go back to being what they are not).

Both the choice of the author and the lyrics reflect well Gonzalez's cultural heritage and his specific interest in 'crossing the line' between the material and imaginary worlds. Cortázar was an Argentine writer, but he was born in Belgium, not unlike Budapest-born Cuban Gonzalez. Moreover, he was known for his interest in and sympathy for Cuba and his oeuvre acts as an emblem of pan-South American movement of magic realism. The poem itself points to the fluidity of identity, an idea to which Gonzalez alludes both in his lyrics and in the interviews.

Likewise, music conveys a feeling of being out of time, away from realistic places and spaces. This effect is achieved by drawing on plethora of influences. Palermo plays Afropop in 'Yolanda' and 'Mustang', recalls the Western pop-rock genre in 'Tiger, Tiger' and uses Mexican influences in 'Sun in Splendour'. The mixture of different eras of pop music is also apparent in 'Sun in Splendour', a song similar to the Beatles' 'psychedelic' songs, such as 'With You Without You'. The large number of instruments, including a trumpet, two saxophones and a conga, and in some live shows, a steel drum and violin (particularly in the early songs), allows Fran Palermo to create a rich, eclectic sound, which brings association with different cultures and moments of time. In common with lyrics, the music also gives impression of being on the move, for example through using the 'galloping guitar' effect, common in soundtracks for Westerns. Such effect, bringing to mind riding on the horseback, is created, among others, 'Next Winds', 'Requiem Nr 21', 'Volcanoes' and 
'Coll del Portell'. In addition, Gonzalez's lead vocals are frequently distorted, which creates an impression that the singer reaches out to us from a distance.

\section{$\underline{\text { Performance and visual heterogeneity of Fran Palermo }}$}

Due to having limited financial resources, to this point (October 2016) Fran Palermo has not produced any professional videos. However, many of its concerts were recorded on camera and uploaded to YouTube and they testify to the changes in its image and especially the transformation of the stage persona of Gonzalez. The earliest of them come from a concert given in July 2011 during Veszprémi Utcazene Fesztivál, when they sang the previously mentioned 'Hava Nagila', 'Bella Ciao' and 'Balkanski Bal'. True to the title of the last song, at the time the band gave the impression of being 'Balkan', according to a dominant stereotype: noisy, uncontrollable, exhibiting, as Slavoj Žižek puts it, a 'prodigious lust for life' (Žižek 2000: 5), as presented in the films by Emir Kusturica. In their performance of 'Balkanski Bal' we see Gonzalez jumping up and down, singing in a broken Serbian adding frequently 'Hey Hey Hey' and 'Ho Ho Ho', throwing his hand to the audience, as if inviting them to join in fun. At one point another member of the band shoots into the audience with a water pistol. Although it is only an innocuous toy, it brings association with the (in)famous Balkan violence, associated also with the genre of Turbo folk. ${ }^{10}$ The atmosphere is of a village market, rather than of a large music festival, aimed at an urban middle class audience. Another early trace of Fran Palermo's activity are still photographs from 2011 accompanying its performance of 'For the Windows in Paradise'. They show the band playing in what looks like a private house, sitting around a large table, with a small audience occupying the floor. These photos project Fran Palermo as a 'fan band' entertaining their friends.

In the subsequent recordings we witness a gradual professionalization and 'deBalkanization' of the band, with stage and audience being increasingly separated and Gonzalez positioning himself at the front of the band with the rest of the musicians from Fran Palermo looking like his supporting band. His image has also been undergoing a significant transformation. In the earlier performances, he typically wears dark trousers, loose sweatshirts or simple T-shirts and long hair, and he plays a guitar and on one occasion a trumpet. At times his appearance verges on being scruffy. Overall, this image fits the idea of an 'authentic' folk singer in the vein of Bob Dylan, who is focused merely on his music, as opposed to his image. In the East European context one can think about the Yugoslav band Bijelo Dugme and its leader Goran Bregović. The gradual de-Balkanization of Fran Palermo is also conveyed by the change of the songs which they have covered over the years. While in their early years we find songs suitable for communal festivity, such as the previously mentioned 'Hava Nagila', later covers betray identification with Anglo-American music, as exemplified by 'Hey Hey Now' by the Cloud Room, 'Rocks' by Primal Scream and several songs from the repertoire of California-based the Growlers. In his later performances Gonzalez also shows a penchant for black music, as demonstrated by covering 'See-Line Woman' from the repertoire of Nina Simone and 'Mama Said' by the 1960s girl group the Shirelles (possibly accessed via the Growlers, who also covered this song). On occasions such songs are performed with black musicians, whose presence adds a certain cultural

\footnotetext{
${ }^{10}$ Significantly, on the Facebook page of Fran Palermo the official beginning of the band is 2012, as if suggesting that the band wanted to erase the 'Balkan' period of its existence from the memory of its fans and their own.
} 
capital to their performance, suggesting that it is a 'real thing' rather than a simulacra. In the last year or so Mark Ronson's 'Daffodils' has occupied a special place in Fran Palermo's performances. Not only is this track included in practically every concert from this period, but its version is very elaborated, including a fragment from 'Raiders of the Storm' and is used as an opportunity to show off Gonzalez's dancing skills.

Already in the Burberry video to 'Am I Right Boy', shot in London, the 'Balkan' traces of Gonzalez's image and persona are all gone. True to its title, Gonzalez comes across as an innocent 'boy', whose ethnicity is difficult to gauge, lost on the streets of London. His appearance brings to mind characters in Jean-Luc Godard's new wave films, such as A bout de souffle and Pierrot le fou, as well as characters created by Louis Garrel, often in the films inspired by Godard, most importantly The Dreamers by Bernardo Bertolucci.

Still 2

Fran Palermo in performance

Upon his return to Hungary, from 2015 onwards, Gonzalez has appropriated several visual styles, on occasions overlapping with each other. One can be described as that of a western dandy or a 'lad'. In some videos we can see him wearing white trousers and white or striped jackets, emphasising his slim, almost androgynous body. Shorter hair and sunglasses, which signify a need to protect oneself from prying eyes, rather than sun rays (although his sunglasses can be also interpreted as a sign of his yearning for sun, as conveyed also by the songs' lyrics), complete this 'cool' image, bringing to mind Liam Gallagher of Oasis. Increasingly we can see him singing without a guitar, which allows him to move freely on stage and interact with his audience, even titillate his (female) fans excited by his proximity. In one of his most recent clips, in which Gonzalez as Henri Gonzo performed with Péterfy Bori \& Love Band, the dandy metamorphosed into a glam rock star, wearing a long, shiny silver coat, probably borrowed from Bori Péterfy. One could not imagine a more different image to that at the beginning of his career. The second style is that of a 'world musician' wearing colourful shirts and ethnic jewellery. On such occasions, however, we get a sense that Gonzalez is putting on a costume rather than wearing his ordinary clothes. The chameleonic image brings to mind the frequent transformations of David Bowie, yet Gonzalez keeps changing at a faster pace.

The frequent feature of Gonzalez's appearance is a hat. This gives him both a slightly exotic or flamboyant image as hats are rarely spotted on the streets of Budapest. Yet, his hats underwent a transformation; from large fedoras at the beginnings of Fran Palermo's existence, almost covering his face, to much smaller and more 'urban' hats. The transformation points to the previously mentioned trajectory from the Balkan musician to a dandy. It shall be added that Fran Palermo is (literally) a band of many hats, as they are also worn by other members of the band. By and large, there is never any attempt to project a unified style by the band. It feels like each member wears his own clothes, which are largely casual, underscoring Gonzalez's penchant for dressing up and playing a star.

One can also notice a kind of amulet, perhaps doubling as a musical instrument, accompanying Fran Palermo's performances - a string with large shells attached to them, of the sort lucky tourists can find on the beaches of Varadero after a storm. Shells also adore one of Gonzalez's guitars. In the case of a different Eastern European musician, such ornaments can be regarded as kitschy, but on this occasion they perfect the image of an artist who came 
from the land of sun and sandy beaches, but was not able to return there. Another element of their stage design are Chinese-like, very colourful umbrellas, reinforcing their 'world music' image and adding an ironic touch to it, given that the Chinese music is one of the musics the band has not used in their repertoire. ${ }^{11}$

The various types of the South and a desire to move, projected through the lyrics, are reflected in Fran Palermo's record covers, which are designed by Henri Gonzalez himself. The cover for one of the band's early EPs, Sun in Splendour presents an old American car of the type which attract tourists in Havana, hitting a painted wall, on which a giant yellow flower is painted. The flower resembles a sun from which multi-coloured rays spread out. Looked at from a distance, the car, the sun and its surroundings might be taken for a peacock showing its feathers in full glory. Such an image suggests that reality for Fran Palermo is a matter of perception rather than of objective existence, as well as being heterotopian.

The cover for Fran Palermo's first LP, Fran Palermo, shows two hands: one white with black fingernails and one black with white fingernails. They are surrounded by rich areas of what looks like red cloth, which obscures some landscape, perhaps a sea, which the hands try to reach or whose view they try to conceal. This red cloth forms different shapes: of a flower and an exotic bird or a carnival mask with a beak. In this 'sea of red' we can recognise smaller objects, such as a parrot net to a black finger and two smiling women in hats with naked arms, looking like tourists posing for photos in the corner of the frame. Taken separately, these objects awake association with a holiday in an oriental resort. However, their scale and arrangements, and the negative-positive effect of the hands, give the impression of somebody dreaming or having a nightmare about such a holiday rather than actually planning to leave for an oriental paradise. The overall effect is surreal, rather than realistic. One can think about Breton's concept of surreal art as marked by startling juxtapositions of objects of different character and scale, placed in one frame. The overall effect is of a sensuous, 'oriental Magritte'. Not unlike Magritte who defamiliarised the ordinary landscape of bourgeois class to which he belonged, rendering it uncanny, the artwork used for this record signals that their music will not offer the touristy version of oriental music, but come up with something original.

While the cover of Fran Palermo comes across as overcrowded with objects and meanings, the cover of their second LP, Razzle Dazzle, is remarkable for its asceticism. It presents a red male figure in silhouette against yellow background. The man wears a hat and smokes a cigarette, which are common accessories in Gonzalez's artistic life. Such a shift from Fran Palermo to Razzle Dazzle, reflects on the less eclectic character of their second record, perhaps inspired by music in spaghetti westerns. At the same time, the cover is still under the sign of Magritte, suggesting the primacy of dream over material reality.

\section{Conclusions}

In this article we argued that the work of Fran Palermo is transnational by looking at different aspects of their records and performance. We also argued that rather than merely selfcolonising themselves with cultures and musics produced elsewhere, the band produces surreal and heterotopian worlds, often playing with representations of these cultures. We also

\footnotetext{
${ }^{11}$ It might be that the umbrellas were 'borrowed' from the Growlers, who also use them at their concerts.
} 
charted the development of Fran Palermo from being a 'Balkan band' to one embracing 'world music'.

However, so far this textual transnationality has not translated into Fran Palermo's international success. Paradoxically, what allows the band to achieve the remarkable effect of fusing different elements to produce a rich sound, such as the sheer size of the band and the number of instruments they use, adds to their difficulty in seeking international fame, as it renders their international travels and recording costly. At the same time, as we suggested, appreciating certain aspects of their work requires a certain cultural capital, which might elude part of their potential audience and hence impede their domestic career.

\section{$\underline{\text { References }}$}

Balkányi, Nóra. 2015. 'Kábé esti, tengerpart melletti buli'. [Sort of a party at night by the seaside] HVG.hu, 05/19/2015. URL:

http://hvg.hu/kultura/20150519_fran_palermo_esti_tengerparti_buli (accessed 8 October 2016).

Barton, Laura. 2013. 'Burberry's Christopher Bailey on his obsession with music', The Guardian, 4 September. https://www.theguardian.com/fashion/2013/sep/04/christopherbailey-music-burberry-fashion (accessed 12 August 2016).

Beaujour, Elizabeth Klosty. 1995. 'Bilingualism'. In The Garland Companion to Vladimir Nabokov, ed. Vladimir E. Alexandrov. 37-43. New York \& London: Garland.

Bohlman, Philip V. 2002. World Music: A Very Short Introduction. Oxford: Oxford University Press.

Broman, Per F. 2005. "'When All Is Said and Done": Swedish ABBA Reception during the 1970s and the Ideology of Pop', Journal of Popular Music Studies, 1: 45-66.

Connell, John and Chris Gibson. 2003. Sound Tracks: Popular Music, Identity and Place. London: Routledge.

Csatári, Bence and Béla Szilárd Jávorszky. 2016. 'Omega: Red Star from Hungary’. In Popular Music in Eastern Europe: Breaking the Cold War Paradigm, ed. Ewa Mazierska 265-282. London: Palgrave.

Di Stefano, John. 2002. 'Moving Images of Home', Art Journal 61 (4): 38-51.

Erlmann, Veit. 1996. 'The Aesthetics of the Global. Imagination: Reflections on. World Music in the 1990s', Public Culture, 8: 467-487.

Fesztival.mandiner.hu. 2015. 'Az első igazi fesztivál megvágott, mint a sújtólég’ [An Interview with Gábor Presser], http://fesztival.mandiner.hu/cikk/20150812_presser_gabor_az_elso_igazi_fesztival_megvago tt_mint_a_sujtoleg (accessed 18 July 2016). 
Foucault, Michel. 1998 [1986]. 'Of Other Spaces', trans. Jay Miskowiec, In The Visual Culture Reader, ed. Nicholas Mirzoff 229-36. London: Routledge, sec. edition.

Gorbachev, Aleksandr. 2015. 'How to Make it in America, Russian Indie Band-Style' Newsweek, 6 June, http://europe.newsweek.com/russian-indie-bands-take-america328349?rm=eu (accessed 19 July 2016).

Guilbault, Jocelyne. 2001. 'World music'. In The Cambridge Companion to Pop and Rock, ed. Simon Frith, Will Straw and John Street 176-192. Cambridge: Cambridge University Press.

House, Juliane. 2003. 'English as a lingua franca: A threat to multilingualism', Journal of Sociolinguistics, 7 (4): 556-78.

Klág, Dávid. 2016. 'Azt hiszik, hogy a Szovjetunióból kikászálódó barmok vagyunk' http://index.hu/kultur/zene/2016/06/25/s_olbricht_farbwechsel_mikolai_martin_interju/, 8 April (accessed 20 July 2016).

MacCannell, Dean. 1999. The Tourist: A New Theory of the Leisure Class. Berkeley: University of California Press.

Mazierska, Ewa. 2015. 'Tourism and Heterotopia in Falco's Songs'. In Relocating Popular Music, ed. Ewa Mazierska and Georgina Gregory 167-85. Palgrave: Macmillan.

Mills, Jane. 2014. 'Sojourner Cinema: Seeking and Researching a New Cinematic Category', Framework 55 (1): 140-164.

Mitchell, Tony. 1996. Popular Music and Local Identity: Rock, Pop and Rap in Europe and Oceania. London: Leicester University Press.

Ramet, Sabrina Petra. 1994. 'Rock: The Music of Revolution (and Political Conformity)'. In Rocking the State: Rock Music and Politics in Eastern Europe and Russia, ed. Sabrina Petra Ramet 1-14. Boulder: Westview Press.

Recorder.blog.hu (2011): Magyar hálószobapop - Kis színtértörténet. Recorder, 24 September, http://recorder.blog.hu/2011/09/24/magyar_haloszobapop (accessed 4 August 2016)

Regev, Motti. 2013. Pop-rock Music: Aesthetic Cosmopolitanism in Late Modernity. Cambridge: Polity. Ryback, Timothy W. 1990. Rock Around the Bloc: A History of Rock Music in Eastern Europe and the Soviet Union. Oxford: Oxford University Press.

Said, Edward W. 2003. [1978]. Orientalism. London: Penguin. 
Szemere, Anna. 2001. Up from the Underground: The Culture of Rock Music in Postsocialist Hungary. University Park: The University State University Press.

Taylor, Timothy, D. 1997. Global Pop: World Music, World Markets. London: Routledge. Zene.ro. 2012. 'Fran Palermo: Kislemez és turné! Zene.ro, 25 February, https://www.zene.ro/zenei-hirek/fran-palermo-kislemez-es-turne/ (accessed 17 July 2016). Žižek, Slavoj. 2000. The Fragile Absolute. London: Verso. 